\title{
The sex-ratio reversal of the Japanese eel Anguilla japonica in the Kaoping River of Taiwan: The effect of cultured eels and its implication
}

\author{
Yu-Wei Chu ${ }^{\text {a,1 }}$, Yu-San Han ${ }^{\text {a, }}$, Chia-Hui Wang ${ }^{\text {a }}$, \\ Chen-Feng You ${ }^{\mathrm{b}}$, Wann-Nian Tzeng ${ }^{\mathrm{a}, *}$ \\ ${ }^{a}$ Institute of Fisheries Science, College of Life Science, National Taiwan University, Taipei, Taiwan, ROC \\ b Department of Earth Sciences, National Cheng-Kung University, Tainan, Taiwan, ROC
}

Received 14 June 2006; received in revised form 13 September 2006; accepted 14 September 2006

\begin{abstract}
The sex ratio of wild Japanese eels in the Kaoping River of southwestern Taiwan has been extremely skewed towards females in the recent years. However, the sex ratio skewed towards males after Typhoon Mindulle, July 2, 2004 then recovered to the previous female-dominated status in the following year. To determine why the sex ratio drastically changed, eels captured in the river were examined by both morphologic characteristics and otolith elemental signatures by solution-based inductively coupled plasma mass spectrometry (SB-ICPMS) and laser-ablation ICPMS (LA-ICPMS). Most of the eels collected in the river after the typhoon had a blue-gray colored back, with morphology and sex ratio similar to that of cultured eels, which differed from wild yellow eels which had a green colored back. The chemical signature in otoliths of eels with a blue-gray colored back was similar to that of cultured eels, with significantly lower $\mathrm{Sr} / \mathrm{Ca}$ ratios but slightly higher $\mathrm{Mn} / \mathrm{Ca}$ ratios than for wild eels. This confirmed that the reversal in eel sex ratio in the Kaoping River estuary resulted from cultured eels that had escaped from eel farms. Eel farmers estimated that about 30,000 eels escaped during the typhoon, sufficient to reverse the sex ratio of the eels in the river. Furthermore, silver eels caught in the estuary in the winter 2004 were also mostly males. The chemical signature in otoliths of these silver eels was similar to that of escaped cultured eels. Their morphology and mean GSIs, however, were comparable to wild silver eels. Thus, cultured eels that have escaped from eel farms can silver normally in the wild. Consequently, cultured eels may help to balance the sex ratio of the wild eel population and may contribute to the spawning stock of Japanese eel.
\end{abstract}

(C) 2006 Elsevier B.V. All rights reserved.

Keywords: Elemental signature; Japanese eel; Otolith; Sex ratio; Typhoon Mindulle

* Corresponding author. Current address: Institute of Fisheries Science, College of Life Science, National Taiwan University, Taipei, Taiwan 106, ROC. Tel.: +886 2 33662887; fax: +886223639570.

E-mail address:wnt@ntu.edu.tw (W.-N. Tzeng).

${ }^{1}$ Both authors contribute equally to this paper.

\section{Introduction}

The Japanese eel, Anguilla japonica Temminck and Schlegel, is a catadromous fish (Ege, 1939). At maturity, the eel migrates from its diverse habitats to a marine spawning site around seamounts west of the Mariana Islands (Tsukamoto, 1992, 2006; Tsukamoto et al., 1998). 
The eel larvae (leptocephali) are transported by the North Equatorial Current and Kuroshio Current from the spawning ground to the continental shelf of East Asian countries (Tesch, 1977; Tsukamoto, 1992; Cheng and Tzeng, 1996, 2003), then metamorphose into glass eels and become elvers in estuaries. The elvers grow as yellow eels for 4-10 yr then metamorphose into silver eels (Tzeng et al., 2000; Han et al., 2003). After metamorphosis, silver eels migrate back to their birthplace to spawn and die.

The eel before the elver stage is considered to be intersexual. Sexually undifferentiated elvers can be feminized by treatment with estrogen (Degani and Kushnirov, 1992; Satoh et al., 1992; Chiba et al., 1993), indicating that the sex of the eel is labile. The sexual differentiation of the eel is thought to be phenotypedependent and to occur at the yellow eel stage (Colombo and Grandi, 1996; Han and Tzeng, 2006). The habitat in which eels grow might affect their sex differentiation. Individual growth rate (Helfman et al., 1987; Holmgren and Mosegaard, 1996), temperature (Holmgren, 1996), latitude (Vladykov, 1966; Helfman et al., 1987) and river types (Sinha and Jones, 1967; Oliveira et al., 2001) have been proposed to be the possible extrinsic cues (for review, please see Davey and Jellyman, 2005). However, a lot of studies indicate that the population density play an important role on eel sex determination, i.e., at high population densities, males dominate and at low population densities females dominate (Parsons et al., 1977; Degani and Kushnirov, 1992; Roncarati et al., 1997; Krueger and Oliveira, 1999; Oliveira et al., 2001; Tzeng et al., 2002a; Han and Tzeng, 2006). In the wild, eel sex ratios vary widely, ranging from almost all males to predominantly females (Matsui, 1972; Parsons et al., 1977; Tesch, 1977; Jessop, 1987; Tzeng et al., 1995, 2002a; Oliveira, 1997, 1999; Oliveira and McCleave, 2000; Oliveira et al., 2001; Han et al., 2003; McCleave and Jellyman, 2004; Han and Tzeng, 2006). The sex skewness of the eel is probably an adaptive strategy for achieving maximum fitness. Although the mean age at maturation of the eel is negatively correlated to the mean growth rate in both sexes (Svedäng et al., 1996; Tzeng et al., 2000, 2002a), male eels might prefer a time-minimizing growth strategy by maturing as soon as possible while females prefer a size-maximizing growth strategy to attain higher fecundity (Vøllestad and Jonsson, 1986; Helfman et al., 1987; Larsson et al., 1990; Vøllestad, 1992; Tzeng et al., 2002a; Han and Tzeng, 2006). In high-density eel habitats with limited food resources, eels preferentially differentiate into males and mature at a young age so that an earlier spawning migration reduces conspecific competition. In contrast, in low-density eel habitats with plentiful food, eels differentiate into females to fully utilize their habitat, and grow and mature at a larger size so as to achieve higher fecundity and increased reproductive success (Helfman et al., 1987; Tzeng et al., 2000, 2002a,b; Han and Tzeng, 2006). However, the abundance of wild Japanese, American and European eel populations have recently declined to approximately $1-$ $10 \%$ of those 20 years ago (Dekker, 2003; Tatsukawa, 2003). Severely low eel abundance might result in a widespread sex ratio bias and accelerate population collapse. Thus, in addition to passive habitat protection and over-fishing prevention, an active strategy like restocking young eels should be considered.

The fish otolith is an aragonite crystal mainly composed of calcium carbonate in an organic matrix together with trace elements incorporated from the ambient water that is a natural tag useful as a tool to study the migratory environmental history of fish (Campana, 1999; Campana and Thorrold, 2001; Tzeng et al., 2002b; Tzeng, 2004). The elemental compositions of different water masses in which fish live usually differ. Thus, fish collected from different geographic areas can be distinguished based on the trace elements of their otoliths (Gillanders and Kingsford, 2000; Rooker et al., 2001, 2003). Accordingly, otolith trace elements may be used to discriminate eel groups of different life history.

In East Asia, the Japanese eel is a commercially important cultured species. For cultivation purposes, elvers in the estuary have been overexploited for many years, which is one of the important reasons for the severe decline of eel populations (Tzeng, 1984, 1985, 2004; Tzeng et al., 1995; Liao, 2001; Tatsukawa, 2003). The population densities of eel in the rivers of Taiwan have been low with sex ratios skewed towards females for many years (Tzeng et al., 2002a; Han and Tzeng, 2006). Interestingly, the eel sex ratio suddenly skewed towards males in the Kaoping River after Typhoon Mindulle, July 2, 2004 for a half year and then recovered to the previous female-dominant status in the following year. The sex ratio of Japanese eels collected in the Kaoping River from 1998 to 2005 together with their morphological characteristics and otolith trace elements were analysed to investigate this novel phenomenon. Our results strongly suggest that the eel sex-ratio reversal in the Kaoping River was due to the escape of cultured eels. The ecological and conservation implications of these escaped cultured eels are also discussed.

\section{Materials and methods}

\subsection{Sample collection}

Wild Japanese eels were collected by eel traps in the estuary of the Kaoping River in southwestern Taiwan 
Table 1

Morphometric and physiological indices of the Japanese eel among different groups

\begin{tabular}{|c|c|c|c|c|c|c|c|c|c|c|}
\hline & \multicolumn{5}{|l|}{ Male } & \multicolumn{5}{|l|}{ Female } \\
\hline & W1 & W2 & WC & $\mathrm{S} 1$ & $\mathrm{~S} 2$ & W1 & W2 & WC & S1 & S2 \\
\hline Sample size & 137 & 22 & 467 & 18 & 60 & 886 & 74 & 110 & 51 & 7 \\
\hline TL (mm) & $\begin{array}{l}443.0 \pm \\
29.3\end{array}$ & $\begin{array}{l}484.3 \pm \\
61.4\end{array}$ & $\begin{array}{l}516.5 \pm \\
38.2\end{array}$ & $\begin{array}{l}564.8 \pm \\
14.6\end{array}$ & $\begin{array}{l}525.7 \pm \\
35.0\end{array}$ & $\begin{array}{l}485.6 \pm \\
66.1\end{array}$ & $\begin{array}{l}465.5 \pm \\
77.6\end{array}$ & $\begin{array}{l}512.3 \pm \\
54.7\end{array}$ & $\begin{array}{l}642.2 \pm \\
10.4\end{array}$ & $\begin{array}{l}580.1 \pm \\
53.6\end{array}$ \\
\hline BW (g) & $\begin{array}{l}107.9 \pm \\
22.6\end{array}$ & $\begin{array}{l}171.4 \pm \\
65.5\end{array}$ & $\begin{array}{l}199.0 \pm \\
50.8\end{array}$ & $\begin{array}{l}219.5 \pm \\
21.2\end{array}$ & $\begin{array}{l}193.9 \pm \\
49.2\end{array}$ & $\begin{array}{l}163.6 \pm \\
7.5\end{array}$ & $\begin{array}{l}146.1 \pm \\
85.4\end{array}$ & $\begin{array}{l}190.2 \pm \\
78.4\end{array}$ & $\begin{array}{l}450.6 \pm \\
26.4\end{array}$ & $\begin{array}{l}328.9 \pm \\
137.2\end{array}$ \\
\hline GSI & $\begin{array}{l}0.07 \pm \\
0.02\end{array}$ & $\begin{array}{l}0.10 \pm \\
0.05\end{array}$ & $\begin{array}{l}0.11 \pm \\
0.04\end{array}$ & $\begin{array}{l}0.15 \pm \\
0.01\end{array}$ & $\begin{array}{l}0.16 \pm \\
0.04\end{array}$ & $\begin{array}{l}0.27 \pm \\
0.01\end{array}$ & $\begin{array}{l}0.30 \pm \\
0.07\end{array}$ & $\begin{array}{l}0.43 \pm \\
0.24\end{array}$ & $\begin{array}{l}1.32 \pm \\
0.07\end{array}$ & $\begin{array}{l}1.32 \pm \\
0.39\end{array}$ \\
\hline
\end{tabular}

Mean \pm SD; Abbreviation: TL: total length; BW: body weight; GSI: Gonadosomatic index; W1: wild yellow eel before July 2004; W2: wild yellow eel between July-November 2004; WC: yellow eel with blue-gray back between July-November 2004; S1: wild silver eel before 2004; S2: wild silver eel in 2004.

$\left(120^{\circ} 50^{\prime} \mathrm{E}, 22^{\circ} 40^{\prime} \mathrm{N}\right)$ approximately every $1-2$ months between November 1998 and December 2005. The Japanese eel was divided into 5 groups based on capture time, morphology, and maturation stage (Table 1). The W1 group was wild yellow eels before July 2004, the W2 group was wild yellow eels between JulyNovember 2004, the WC group was yellow eels with a blue-gray back collected between July-November 2004, the S1 group was wild silver eels before 2004, and the S2 group was wild silver eels in 2004. Cultured Japanese eels, originated from glass eels caught at the estuary of the Kaoping River, were purchased from eel farmers near the Kaoping River in 2004. Total length $(\mathrm{TL}, \pm 1 \mathrm{~mm})$ and body weight $(\mathrm{BW}, \pm 0.1 \mathrm{~g})$ of the eels were measured. The gonadosomatic index (GSI) was estimated as gonad weight/body weight $\times 100$. The sex and developmental stage of each eel was determined by body coloration and gonadal histology when possible (Han et al., 2003).

\subsection{Solution-based ICPMS (SB-ICPMS) analyses}

The trace elemental composition of eel otoliths from Kaoping River, which were randomly chosen in 2004 before (W1 group, $N=27,8$ males and 19 females) and after (WC group, $N=20,15$ males and 5 females) Typhoon Mindulle, and 10 pond-cultured eels (sexundetermined, TL: $241.6 \pm 29.3 \mathrm{~mm}$; BW: $15.6 \pm 5.1 \mathrm{~g}$ ) were analyzed by SB-ICPMS. The otoliths were cleaned of organic material with $\mathrm{H}_{2} \mathrm{O}_{2}$, ultrasonically cleaned in double distilled water, and dried in acid-washed microcentrifuge tubes. After weighing on a microbalance (to $0.01 \mathrm{mg}$ ), samples were dissolved in $0.3 \mathrm{~N}$ ultrapure nitric acid and the $\mathrm{Ca}$ concentration adjusted to a range between 2-6 ppm. The nitric acid was also used as a blank solution for calculating detection limits. A laboratory standard, composed of a chemical composi- tion of interest, was analysed during each analysis session. Laboratory standard solutions were prepared at Ca concentrations of $0.5,1,2.5,5$ and $10 \mathrm{ppm}$ for calibration. Extra runs of $2.5 \mathrm{ppm}$ Ca standard solution, used as an internal standard, were made after every 5 samples to monitor for possible instrument drifting. All analyses were run on a Finnigan MAT ELEMENT 2 high-resolution ICPMS (Thermo Electron Corp., Bremen, Germany) equipped with a self-aspirating $(20 \mu \mathrm{L} /$ min) PFA nebulizer (CETAC) and a dual-inlet quartz spray chamber. Preliminary analyses suggested that 7 elements, including $\mathrm{Ca}, \mathrm{Sr}, \mathrm{Na}, \mathrm{Mg}, \mathrm{Mn}, \mathrm{Pb}$ and $\mathrm{Ba}$ were reliably detectable in otoliths and these elements were chosen for analysis.

\subsection{Laser-ablation ICPMS (LA-ICPMS) analyses}

The chronological changes of 4 element/Ca ratios $(\mathrm{Sr} / \mathrm{Ca}, \mathrm{Mn} / \mathrm{Ca}, \mathrm{Ba} / \mathrm{Ca}$ and $\mathrm{Pb} / \mathrm{Ca}$ ) were measured from the otolith edge to edge through the primordium by LAICPMS. 8 samples were randomly chosen from W1 eels ( 2 males and 8 females, TL: $444.7 \pm 96.5 \mathrm{~mm}$; BW: $147.8 \pm 104.6 \mathrm{~g}), 8$ samples randomly chosen from WC eels (7 males and 1 females, TL: $512.5 \pm 36.0 \mathrm{~mm}$; BW: $199.7 \pm 56.9 \mathrm{~g})$, and another 8 samples randomly from the S2 silver eels ( 8 males, TL: $533.9 \pm 36.0 \mathrm{~mm}$; BW: $211.7 \pm 41.3 \mathrm{~g})$. The otoliths were embedded in epofix resin and cut transversely approximately $400 \mu \mathrm{m}$ thick by a slow speed saw (Isomet, Buehler) fitted with a diamond-edged blade. The thin section was ground repeatedly with grinding paper until the annuli were clearly visible and were finally polished with a micro cloth and $0.05 \mu \mathrm{m}$ alumina paste. The LA-ICPMS system consisted of a Merchantek LUV 266 Nd: YAG UV laser microprobe (New Wave Research, Inc.) connected to a Finnigan MAT ELEMENT 2 highresolution ICPMS. Otoliths were ablated inside a sealed 


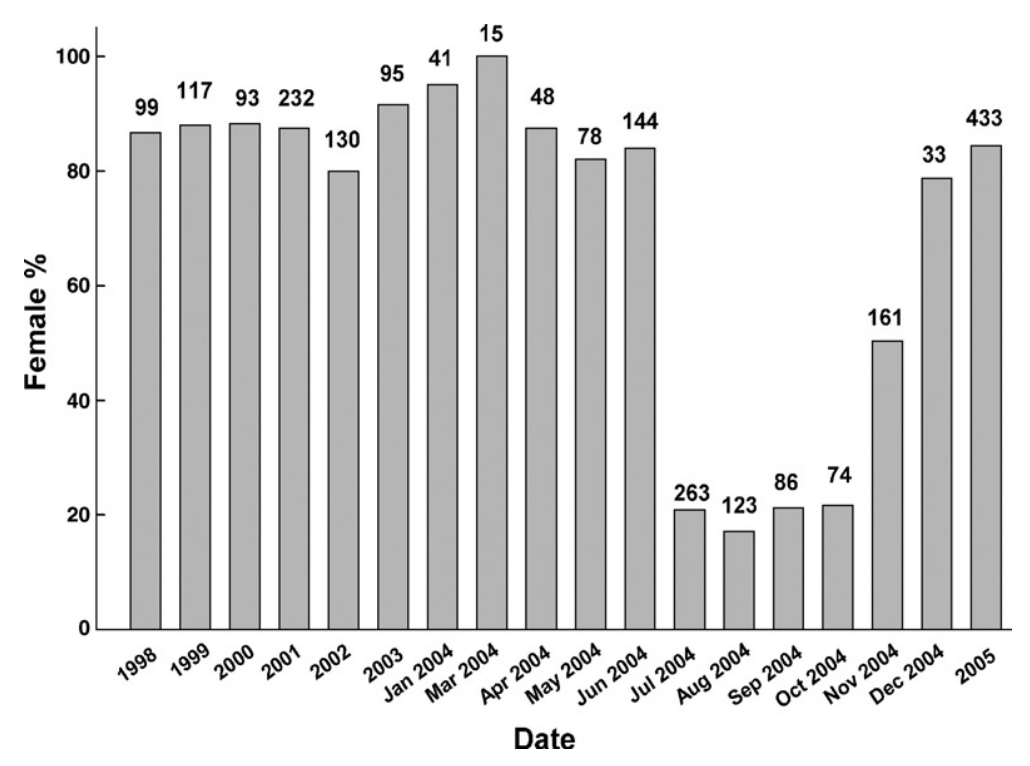

Fig. 1. Eel sex ratios in the Kaoping River of Taiwan from 1998 through 2005 and by month in 2004. Eels included both sex-determined yellow and silver ones. The eels of undetermined sex were excluded from analysis. The numerals above each column indicate the sample size.

chamber and transported to the ICPMS for analysis of $\mathrm{Sr}, \mathrm{Ca}, \mathrm{Mn}, \mathrm{Pb}$ and $\mathrm{Ba}$. Calcium was used as an internal standard and the concentrations of other elements were estimated against the $\mathrm{Ca}$ concentration. The laser was pulsed at $20 \mathrm{~Hz}$ across the transverse section of the otolith, moving from the otolith edge to edge through the primordium with a speed of $15 \mu \mathrm{m} / \mathrm{s}$. Each data point took about $2.46 \mathrm{~s}$ and represents the chemical composition over $37 \mu \mathrm{m}$. The first 3 data points from the primordium represented the otolith elemental composition of the larval period before elver stage, and the subsequent points represented that of the yellow stage.

\subsection{Data analyses}

Statistical differences in the sex ratios of wild eels among different times (Fig. 1) and between eel groups of

Table 2

Comparison of the sex ratio among yellow stage Japanese eels of different groups

\begin{tabular}{lrrrl}
\hline & $\begin{array}{l}\text { Sample } \\
\text { size }(n)\end{array}$ & \multicolumn{2}{l}{ Number of eels } & \\
\cline { 3 - 4 } & Male & Female & & $\begin{array}{l}\text { Female } \\
\text { percentage } \\
(\%)\end{array}$ \\
\hline W1 & 1023 & 137 & 886 & 86.6 \\
W2 & 96 & 22 & 74 & 77.1 \\
WC & 577 & 467 & 110 & 19.1 \\
C & 34 & 28 & 6 & 18.0 \\
\hline
\end{tabular}

W1: wild yellow eel before July 2004; W2: wild yellow eel between July-November 2004; WC: yellow eel with blue-gray back between July-November 2004; C: cultured eel in 2004.
W1/W2, WC/C and S1/S2 were examined with the Chisquare test of homogeneity. Differences in the mean TL, BW and GSI between different eel groups of the same sex were examined using analysis of variance (ANOVA). The concentration of elements measured by SB- and LA-ICPMS were standardized as elementto-calcium ratios. All of the ratios were $\log _{10^{-}}$ transformed to meet the assumptions of normal distribution and homogeneity of variance when performing ANOVA followed by Tukey HSD test. Statistical significance was accepted at $\alpha=0.05$.

\section{Results}

\subsection{Dynamics of eel sex ratio in the Kaoping River}

A total number of 1092 and 1173 sex-determined Japanese eels were analyzed before and after Typhoon Mindulle, July 2, 2004 (Table 1, Fig. 1). The annual and monthly proportions of female Japanese eels collected from 1998 through June 2004 in the Kaoping River ranged between $80 \%$ and $95 \%$, and did not differ significantly among this periods $\left(\chi^{2}=18.48, d f=10\right.$, $0.025<p<0.05$ ) (Fig. 1). However, the sex ratio suddenly skewed to the male after Typhoon Mindulle, which lasted for about 5 months (July-November) with significant lower proportions of female eels (between $17.1 \%-50.3 \%$ ) than in the previous years $\left(\chi^{2}=668.3, d f=15, p<0.005\right)$ (Fig. 1). The proportions of female eels recovered to the female-dominant status (84.5\%) in 2005 (Fig. 1). 
Table 3

Comparison of the sex ratio of silver Japanese eels for the year before 2004 and in 2004

\begin{tabular}{|c|c|c|c|c|}
\hline & \multirow{2}{*}{$\begin{array}{l}\text { Sample } \\
\text { size }(n)\end{array}$} & \multicolumn{2}{|c|}{ Number of eels } & \multirow{2}{*}{$\begin{array}{l}\text { Female } \\
\text { percentage } \\
(\%)\end{array}$} \\
\hline & & Male & Female & \\
\hline $\mathrm{S} 1$ & 67 & 18 & 51 & 76.1 \\
\hline S2 & 67 & 60 & 7 & 10.4 \\
\hline
\end{tabular}

S1: wild silver eel before 2004; S2: wild silver eel in 2004.

Eel groups W1 and W2 were both dominated by females and had similar sex ratios $\left(\chi^{2}=4.18, d f=1\right.$, $0.025<p<0.05$ ) (Table 2). The WC eel group, however, was dominated by males, as was the cultured eels (C group) ( $\left.\chi^{2}=0, d f=1, p>0.05\right)$. On the other hand, the sex ratios of silver eels (S1) were female-dominant and significantly differed from the male-dominant S2 eel group $\left(\chi^{2}=61.3, d f=1, p<0.005\right)$ (Table 3$)$.

\subsection{Comparison of morphological index among eel groups}

The W1 and W2 yellow eels had white-gray on the pectoral fins, green on the back and yellow-white on the belly. The WC eels had blue-gray back and white on the belly. The S1 and S2 silver eels had dark pigmentation on the back and pectoral fins, and silver/bronze on the belly and larger eyes. For males, the mean values of TL,
BW and GSI were significantly larger in S1 than in W1 or W2 $(p<0.001)$ (Table 1). The mean TL and BW of W1 males were comparable with W2 but significantly lower than those of the WC males $(p<0.001)$. The mean TL and BW of WC males were comparable to those of $\mathrm{S} 1$ or S2 males (TL: $p=0.07$; BW: $p=0.28$ ). The mean GSI of WC males ranged between that for W1 and S2 males without significant differences $(p>0.05)$. For females, the mean TL, BW and GSI were significantly higher for S1 females than for W1 or W2 females $(p<0.001)$. The WC females had significantly lower mean TL, BW and GSI than the S2 females. $(p<0.01)$. Both sexes of the W2 group showed mean TL, BW and GSI similar to the values for comparable sexes of the $\mathrm{W} 1$ group $(p>0.05)$. The mean TL, BW and GSI of S1 and S2 groups on both sexes were comparable to each other without significant differences $(p>0.05)$.

\subsection{Comparison of elemental composition in the otolith among eel groups using SB-ICPMS}

The W1 eel group had a significantly higher $\mathrm{Sr} / \mathrm{Ca}$ ratio than the $\mathrm{C}$ eel group $(p<0.001)$ (Fig. 2a). In contrast, the $\mathrm{Mn} / \mathrm{Ca}$ ratio was significantly higher in the $\mathrm{C}$ eel group than in the W1 eel group $(p<0.001)$ (Fig. 2d). In other words, both $\mathrm{Sr} / \mathrm{Ca}$ and $\mathrm{Mn} / \mathrm{Ca}$ ratios could discriminate between $\mathrm{W} 1$ and $\mathrm{C}$ eel groups. However, no significant differences for either $\mathrm{Sr} / \mathrm{Ca}$ or $\mathrm{Mn} / \mathrm{Ca}$ ratios

(c)

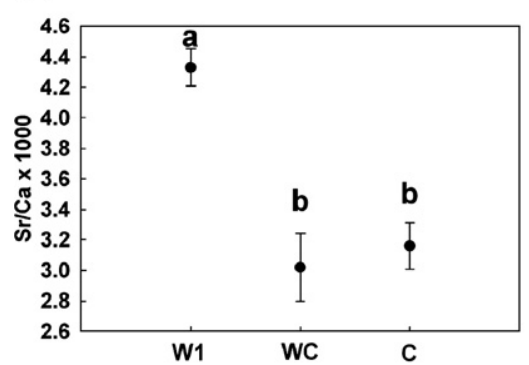

(b)
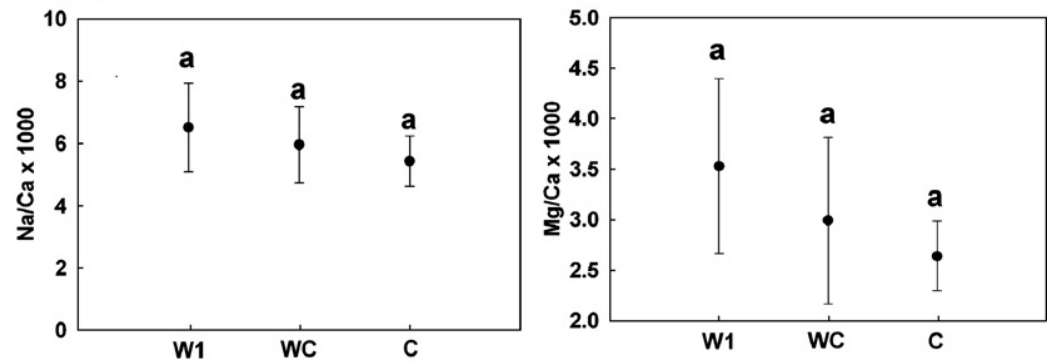

(e)
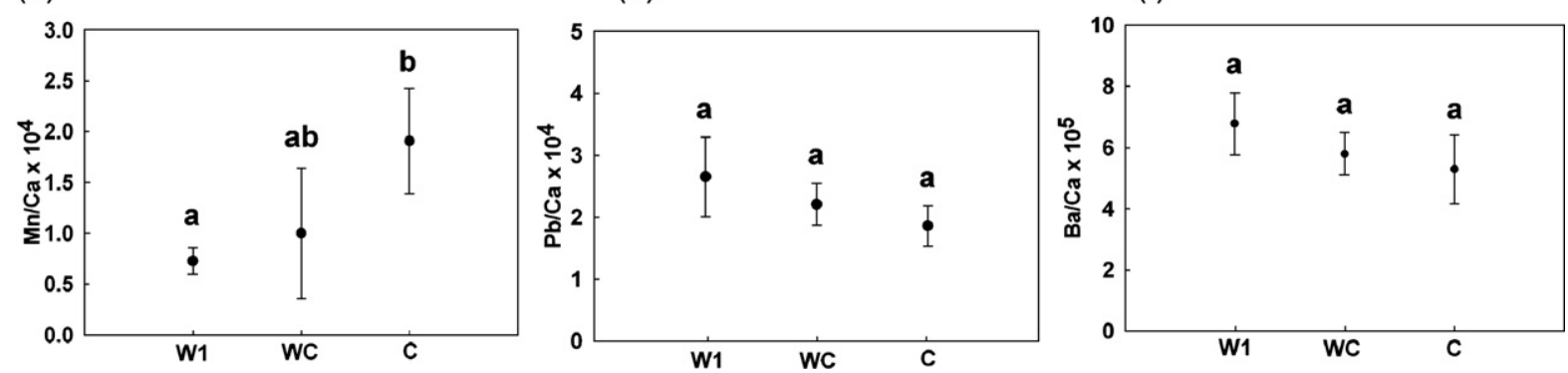

Fig. 2. Comparison of mean ( $\pm 95 \% \mathrm{CI}$ ) otolith (a) $\mathrm{Sr} / \mathrm{Ca}$ ratios, (b) $\mathrm{Na} / \mathrm{Ca}$ ratios, (c) $\mathrm{Mg} / \mathrm{Ca}$ ratios, (d) $\mathrm{Mn} / \mathrm{Ca}$ ratios, (e) $\mathrm{Pb} / \mathrm{Ca}$ ratios and (f) $\mathrm{Ba} / \mathrm{Ca}$ ratios among wild $(\mathrm{W} 1, N=27)$ and cultured $(\mathrm{WC}, N=20 ; \mathrm{C}, N=10)$ eel groups. Different letters above the bars indicate that the differences are statistically significant $(p<0.05)$. 
were observed between $\mathrm{WC}$ and $\mathrm{C}$ eel groups. The other four elements-to-Ca ratios of $\mathrm{Na} / \mathrm{Ca}, \mathrm{Mg} / \mathrm{Ca}, \mathrm{Pb} / \mathrm{Ca}$ and $\mathrm{Ba} / \mathrm{Ca}$ showed no differences among the three eel groups (Fig. 2b,c,e,f).

\subsection{Comparison of elemental composition of the otolith among eel groups using LA-ICPMS}

Temporal changes in the 4 mean element-to-Ca ratios $(\mathrm{Sr} / \mathrm{Ca}, \mathrm{Mn} / \mathrm{Ca}, \mathrm{Pb} / \mathrm{Ca}$ and $\mathrm{Ba} / \mathrm{Ca}$ ) scanned from otolith edge to edge through the primordium for the $\mathrm{W} 1, \mathrm{WC}$ and $\mathrm{S} 2$ eel groups are shown in Fig. 3. The ontogenetic changes in otolith $\mathrm{Sr} / \mathrm{Ca}$ ratios decreased from the primordium to the elver check at a distance $60-100 \mu \mathrm{m}$, which was deposited when the glass eel became elver. Beyond the elver check, the mean $\mathrm{Sr} / \mathrm{Ca}$ ratio of the $\mathrm{W} 1$ eel group was significantly higher than for the other two

(a)

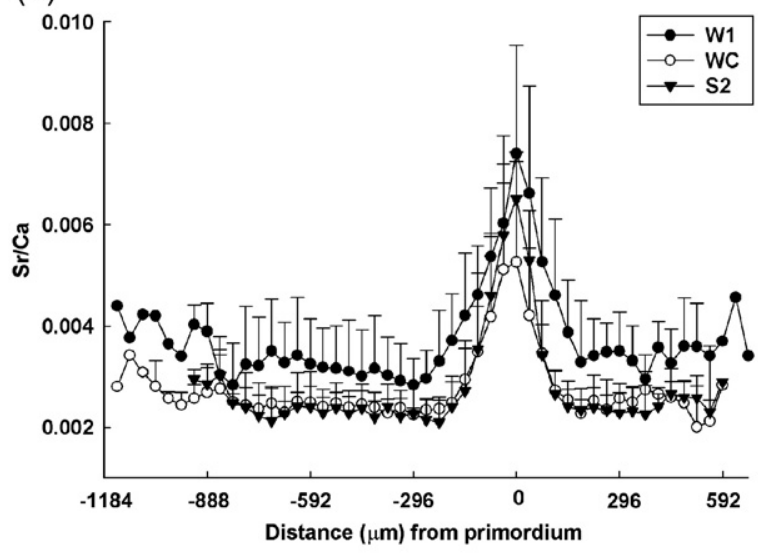

(c)

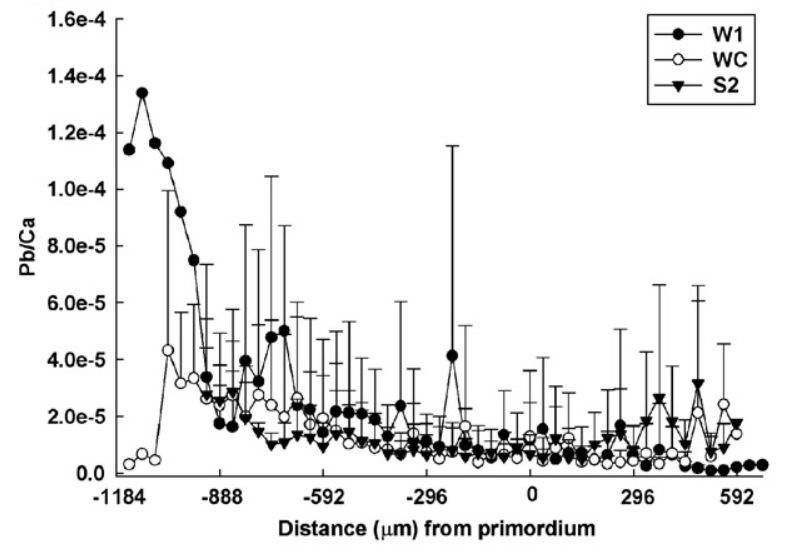

eel groups $(p<0.05)$ (Table 4$)$. No significant differences in $\mathrm{Sr} / \mathrm{Ca}$ ratios occurred between the $\mathrm{WC}$ and $\mathrm{S} 2$ eel groups $(p>0.05)$. The otolith $\mathrm{Mn} / \mathrm{Ca}$ ratios in $\mathrm{W} 1$ group showed no ontogenetic change. The WC and S2 eel groups, however, showed higher $\mathrm{Mn} / \mathrm{Ca}$ ratios near the elver stage than those for the W1 eel group (Fig. 3b). The mean $\mathrm{Mn} / \mathrm{Ca}$ ratio beyond the larval stage of the $\mathrm{S} 2$ eel group was significantly higher than for the W1 eel group $(p<0.05)$ (Table 4$)$. No significant difference occurred between the mean $\mathrm{Mn} / \mathrm{Ca}$ ratios for the $\mathrm{WC}$ and $\mathrm{S} 2$ eel groups $(p>0.05)$. Similar to the data from the SB-ICPMS, both $\mathrm{Sr} / \mathrm{Ca}$ and $\mathrm{Mn} / \mathrm{Ca}$ ratios from the LAICPMS could discriminate between eels from the W1 and $\mathrm{S} 2$ groups. Ontogenetic patterns of $\mathrm{Pb} / \mathrm{Ca}$ ratios were similar among the three eel groups (Fig. 3c) without significant differences $(p>0.05)$ (Table 4). The ontogenetic changes of $\mathrm{Ba} / \mathrm{Ca}$ ratios were higher in the

(b)

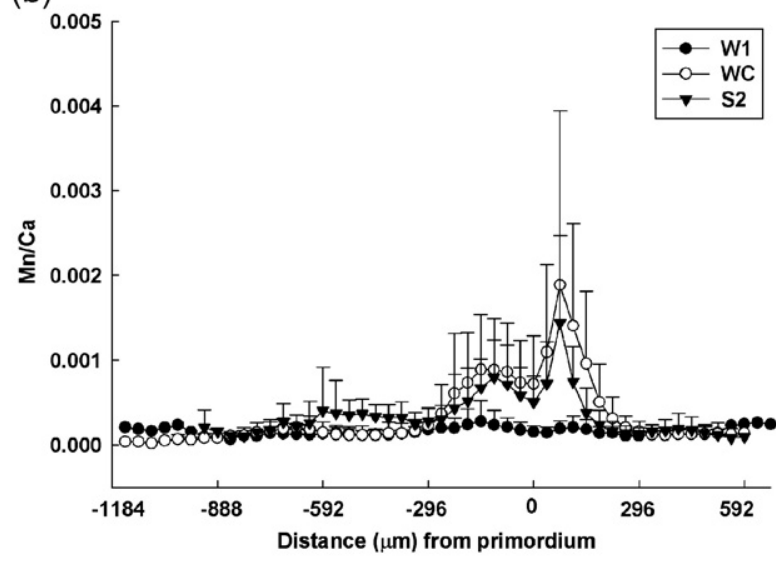

(d)

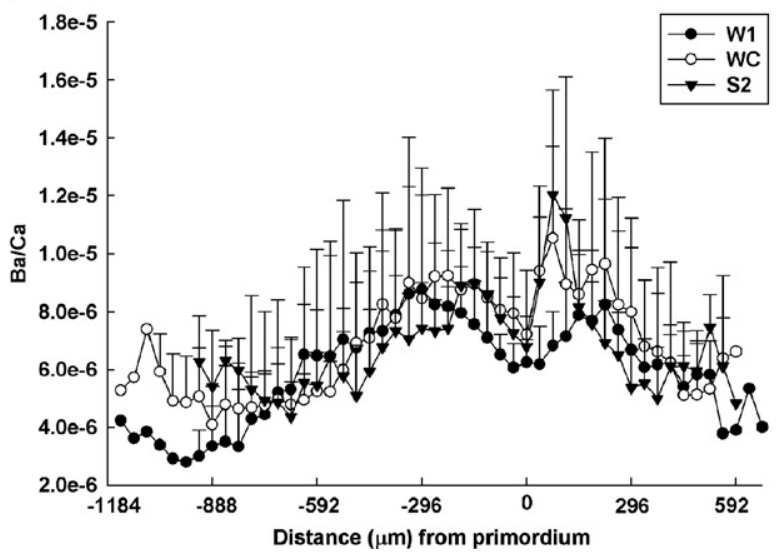

Fig. 3. Temporal changes in 4 mean element/Ca ratios (mean $\pm \mathrm{SD})$ scanned from the otolith edge to edge through the primordium for the $\mathrm{W} 1(N=8)$, WC $(N=8)$ and S2 $(N=8)$ eel groups. Each spot of the elemental composition measured by LA-ICPMS was approximately $37 \mu \mathrm{m}$ in diameter. The otolith primordium was located at the zero point. 
Table 4

Comparison of otolith trace elements after the larval stage among Japanese eels of different groups using LA-ICPMS

\begin{tabular}{|c|c|c|c|c|}
\hline \multirow{2}{*}{$\begin{array}{l}\text { Element/ } \\
\mathrm{Ca}\end{array}$} & \multicolumn{3}{|c|}{ Mean $\pm \mathrm{SD}^{*}$} & \multirow{2}{*}{$\begin{array}{l}\text { Tukey HSD } \\
\text { test }\end{array}$} \\
\hline & $\mathrm{W} 1(n=8)$ & $\mathrm{WC}(n=8)$ & $\mathrm{S} 2(n=8)$ & \\
\hline $\mathrm{Sr} / \mathrm{Ca}$ & $3.45 \pm 0.51$ & $2.56 \pm 0.12$ & $2.55 \pm 0.51$ & $\mathrm{~W} 1>\mathrm{WC}=\mathrm{S} 2$ \\
\hline $\mathrm{Mn} / \mathrm{Ca}$ & $1.53 \pm 0.71$ & $2.67 \pm 1.66$ & $3.95 \pm 1.53$ & $\mathrm{~W} 1<\mathrm{S} 2$ \\
\hline $\mathrm{Pb} / \mathrm{Ca}$ & $2.11 \pm 1.20$ & $1.47 \pm 1.01$ & $1.09 \pm 0.69$ & $\mathrm{~W} 1=\mathrm{WC}=\mathrm{S} 2$ \\
\hline $\mathrm{Ba} / \mathrm{Ca}$ & $6.77 \pm 1.72$ & $6.93 \pm 1.75$ & $6.88 \pm 1.40$ & $\mathrm{~W} 1=\mathrm{WC}=\mathrm{S} 2$ \\
\hline
\end{tabular}

* $\mathrm{Sr} / \mathrm{Ca}: \times 10^{3} ; \mathrm{Mn} / \mathrm{Ca}: \times 10^{4} ; \mathrm{Pb} / \mathrm{Ca}: \times 10^{5} ; \mathrm{Ba} / \mathrm{Ca}: \times / 10^{6}$.

Abbreviation: W1: wild yellow eel before July 2004; WC: yellow eel with blue-gray back between July-November 2004; S2: silver eel in 2004.

elver stage than in the larval and yellow stages (Fig. 3d), and there were no significant differences in the mean $\mathrm{Ba} /$ Ca ratios among the three eel groups $(p>0.05)$ (Table 4$)$.

\section{Discussion}

The sex ratio of wild Japanese eels in the Kaoping River of southwestern Taiwan was extremely skewed towards females between 1998-2002 (Han and Tzeng, 2006). A similar result was found in 2003 and the first half of 2004. However, the sex ratio suddenly skewed towards males after Typhoon Mindulle (July 2, 2004) and this condition lasted for 5 months. More than $85 \%$ of yellow eels sampled between July and November, 2004 had a blue-gray color on the back, as did the cultured eels, which was quite different from normal wild eels with a green colored back. The proportion of female eels in the WC group was similar to that for cultured eels, where males are dominant, in contrast to the female-dominant wild eels. The TL and BW of the WC eel group were also slightly higher than for the wild eels (W1 and W2 eel groups). Thus, the WC eel group probably consisted of escaped pond-cultured eels. This conclusion was further validated by otolith elemental composition analysis using SB-ICPMS. The C and WC groups had a significantly lower mean $\mathrm{Sr} / \mathrm{Ca}$ ratio and a higher mean $\mathrm{Mn} / \mathrm{Ca}$ ratio than the W1 group. No significant difference was found between the WC and $\mathrm{C}$ eel groups for any of the trace elements analysed. Thus, the combined results of the morphological, sex ratio, and otolith microchemistry data indicated that the WC eel group originated from cultured eels which escaped from the eel ponds into the Kaoping River during Typhoon Mindulle.

The population size of wild Japanese eels in the estuary of the Kaoping River was previously estimated to be about 5000-20,000 (Han and Tzeng, 2006). Did sufficient numbers of cultured eels escape after the typhoon to reverse the sex ratio of eels in the Kaoping River estuary? A questionnaire from the owners of the eel farms whose eels escaped during the typhoon estimated that about 30,000 cultured eels escaped, most of which were yellow-stage and reared for 1.5 years after the elver stage. Based on the known eel sex ratio and numbers of local wild and escaped eels, the proportion of females after Typhoon Mindulle can be estimated as $27.8 \%-$ $45.4 \%$, close to the range of female proportions observed in the Kaoping River $(17.1 \%-50.3 \%)$ after the typhoon. Thus, the reversal in eel sex ratio caused by the escaped cultured eels after typhoon is plausible.

The WC-type eels rapidly disappeared after November 2004 and the eel sex ratio recovered to the previous female-dominant status in the following year. During that time, however, the S2 silver eels caught in the estuary in the winter 2004 were mostly male, similar to the WC eel group but different from the previous silver eel pattern. The WC eels had different external colors and lower mean GSIs than S2 eels. The external morphology of S2 silver eels was similar to that of normal S1 silver eels, both with black back and pectoral fins, silver/bronze belly and larger eyes. The GSIs of S1 and S2 eel groups were also comparable to each other. The otolith elemental signature of these S2 silver eels using LA-ICPMS, however, was similar to that of the WC eel group without significant differences. The mean $\mathrm{Sr} / \mathrm{Ca}$ ratios curve for the $\mathrm{S} 2$ and WC eel groups were consistently lower than that for the $\mathrm{W} 1$ eel group beyond the elver stage, and their mean $\mathrm{Mn} /$ $\mathrm{Ca}$ ratios curve were higher than that for the Wl eel group during the juvenile stage. Consequently, the combined sex ratio and otolith microchemistry data for the $\mathrm{S} 2$ silver eels suggests that they likely metamorphosed from the WC eels which escaped from the eel ponds into the Kaoping River during Typhoon Mindulle. Thus, these escaped cultured eels can silver normally in a natural environment.

Otolith elemental signatures determined by SBICPMS and LA-ICPMS methods showed similar patterns, indicating a higher $\mathrm{Mn} / \mathrm{Ca}$ ratio and lower $\mathrm{Sr} / \mathrm{Ca}$ ratio in cultured eels than in wild eels. The concentrations of minor and trace elements in the otolith may be influenced primarily by environmental conditions, although physiological processes may also contribute (Kalish, 1989, 1991). Thus, the migratory life history of the fish is recorded in the otoliths (Campana and Neilson, 1985; Campana, 1999). We found that $\mathrm{Mn} / \mathrm{Ca}$ and $\mathrm{Sr} / \mathrm{Ca}$ ratios can discriminate between eels from culture ponds and the wild. The constant lower $\mathrm{Sr} / \mathrm{Ca}$ ratio in the WC/S2 eels than in the $\mathrm{W} 1$ eels from LAICPMS data may be because the water for the culture ponds was mostly well water, which might have lower $\mathrm{Sr}$ concentration compared with estuary water where the W1 eels habituated. The concentration of the $\mathrm{Sr} / \mathrm{Ca}$ ratio is greatest in seawater, middle in the estuary, and lowest in 
freshwater, which positively correlated to $\mathrm{Sr} / \mathrm{Ca}$ ratios in eel otoliths (Tzeng, 1996; Campana, 1999). The higher otolith $\mathrm{Mn} / \mathrm{Ca}$ ratios near the juvenile stage of the $\mathrm{WC} / \mathrm{S} 2$ eel groups than of the W1 eels from LA-ICPMS data, however, might be due to the use of potassium permanganate $\left(\mathrm{KMnO}_{4}\right)$ as the parasiticide in the cultured elvers (personal communication).

In the wild, although the sex ratios of eels in different habitats may vary, the final eel sex ratio may become suitable for maximum population growth when they migrate back to the spawning ground and form a mixed spawning group (Han and Tzeng, 2006). However, studies of Japanese eel resources in the Kaoping and Tanshui River of Taiwan, which have experienced similar fishery and habitat pressures, show a very low population density and reduced eel habitat (Tzeng et al., 1995; Tzeng, 1997; Han and Tzeng, 2006). In Japan, the catches of both glass eels and adult eels have also decreased (Dekker, 2003; Tatsukawa, 2003). The widespread decline of the eel resource throughout Asia might result in a widespread sex ratio bias toward females and catastrophic population collapse. Thus, in addition to habitat protection and prevention of over-fishing to sustain the natural eel resource, restocking by releasing cultured eels may be feasible. We observed that the occasional escape of cultured eels can not only reverse the sex ratio of eels in the wild but that when they silver they have a morphology and mean GSI comparable to the wild silver eels. The disappearance of escaped cultured eels in the Kaoping River estuary in the following year suggests that, although some might be captured, some of them might begin the spawning migration after silvering. In European eel, however, some studies argue that the restocked eels in the Baltic Sea may not find their way out due to lack of orientation imprinting (Westin, 1998), or have not enough lipid content required in swimming and reproduction to the Sargasso Sea (Limburg et al., 2003). The problem might not be serious for the Japanese eel in Taiwan since the glass eels caught in the estuary are cultured in ponds nearby and the cultured eels have more fat content than those in the wild (Han et al., 2000). Furthermore, the spawning of escaped cultured eels should not alter the genetic diversity of the wild population because the cultured eels all originated from the glass eels captured in the wild.

In conclusion, the WC eel group present after Typhoon Mindulle was identified as cultured eels that had escaped from eel farms and which can silver normally in a natural environment. The usually maledominated cultured eels could supplement and balance sex ratio of the wild eels, which were usually femaledominated in low-density population, and might contribute to the spawning stock of the Japanese eel.

\section{Acknowledgement}

This study was financially supported by the National Science Council of the Republic of China (NSC 942313-B-002-070). The authors are grateful to Mr. B. M. Jessop of Canada for reviewing an early draft of the manuscript.

\section{References}

Campana, S.E., 1999. Chemistry and composition of fish otoliths: pathways, mechanisms, and applications. Mar. Ecol., Prog. Ser. 188, 263-297.

Campana, S.E., Neilson, J.D., 1985. Microstructure of fish otoliths. Can. J. Fish. Aquat. Sci. 42, 1014-1032.

Campana, S.E., Thorrold, S.R., 2001. Otoliths, increments, and elements: keys to a comprehensive understanding of fish populations? Can. J. Fish. Aquat. Sci. 58, 30-38.

Cheng, P.W., Tzeng, W.N., 1996. Timing of metamorphosis and estuarine arrival across the dispersal range of the Japanese eel Anguilla japonica. Mar. Ecol., Prog. Ser. 113, 89-96.

Chiba, H., Iwatsuk, K., Hayami, K., Yamauchi, K., 1993. Effect of dietary estradiol-17 $\beta$ on feminization, growth and body composition in the Japanese eel (Anguilla japonica). Comp. Biochem. Physiol. 106A, 367-372.

Colombo, G., Grandi, G., 1996. Histological study of the development and sex differentiation of the gonad in the European eel. J. Fish Biol. 48, 493-512.

Davey, A.J.H., Jellyman, D.J., 2005. Sex determination in freshwater eels and management options for manipulation of sex. Rev. Fish Biol. Fish. 15, 37-52.

Degani, G., Kushnirov, D., 1992. Effects of $17 \beta$-estradiol and grouping on sex determination of European eels. Prog. Fish-Cult. $54,88-91$.

Dekker, W., 2003. Slipping through our hands - Population dynamics of the European eel. PhD dissertation, University of Amsterdam.

Ege, V., 1939. A revision of the genus Anguilla Shaw, a systematic, phylogenetic and geographical study. Dana Rep. 16, 1-256.

Gillanders, B.M., Kingsford, M.J., 2000. Elemental fingerprints of otoliths of fish may distinguish estuarine 'nursery' habitats. Mar. Ecol., Prog. Ser. 201, 273-286.

Han, Y.S., Tzeng, W.N., 2006. Sex ratio as a means of resource assessment for the Japanese eel Anguilla japonica: A case study in the Kaoping River of Taiwan. Zool. Stud. 45, 255-263.

Han, Y.S., Tzeng, W.N., Huang, Y.S., Liao, I.C., 2000. The silvering of the Japanese eel Anguilla japonica: season, age, size and fat. J. Taiwan Fish. Res. 8, 37-45.

Han, Y.S., Liao, I.C., Huang, Y.S., He, J.T., Chang, C.W., Tzeng, W.N., 2003. Synchronous changes of morphology and gonadal development of silvering Japanese eel Anguilla japonica. Aquaculture 219, 783-796.

Helfman, G.S., Facey, D.E., Hales, L.S., Bozeman Jr., E.L., 1987. Reproductive ecology of the American eel. In: Dadswell, M.J., Klauda, R.J., Moffit, C.M., Saunders, R.A., Rulifson, R.L., Cooper, J.E. (Eds.), Common Strategies of Anadromous and Catadromous Fishes. Bethesda, MD: American Fisheries Society Symposium, vol. 1, pp. 42-56.

Holmgren, K., 1996. Effect of water temperature and growth variation on the sex ratio of experimentally reared eels. Ecol. Freshw. Fish 5, 203-212. 
Holmgren, K., Mosegaard, H., 1996. Implications of individual growth status on the future sex of the European eel. J. Fish. Biol. 49, 910-925.

Jessop, B.M., 1987. Migrating American eels in Nova Scotia. Trans. Am. Fish. Soc. 116, 161-170.

Kalish, J.M., 1989. Otolith microchemistry: validation of the effects of physiology, age and environment on otolith composition. J. Exp. Mar. Biol. Ecol. 132, 151-178.

Kalish, J.M., 1991. Determinants of otolith chemistry: seasonal variation in the composition of blood plasma, endolymph and otoliths of bearded rock cod Pseudophycis barbatus. Mar. Ecol., Prog. Ser. 74, 137-159.

Krueger, W., Oliveira, K., 1999. Evidence for environmental sex determination in the American eel, Anguilla rostrata. Environ. Biol. Fish. 55, 381-389.

Larsson, P., Hamrin, S., Okla, L., 1990. Fat content as a factor inducing migratory behavior in the eel (Anguilla anguilla L.) to the Sargasso Sea. Naturwissenschaften 77, 488-490.

Liao, I.C., 2001. A general review on aquaculture in Asia: a focus on anguillid eel. 5th and 6th Asian Fisheries Forums. Chiang Mai, Thailand: AFS Special Publication, vol. 11, pp. 39-54.

Limburg, K.E., Wickström, H., Svedäng, H., Elfman, M., Kristiansson, P., 2003. Do stocked freshwater eels migrate? Evidence from the Baltic suggests 'yes'. Am. Fish. Soc. Symp. 33, 275-284.

Matsui, I., 1972. Unagigaku: Eel Biology. Kosei-sha Kosei-Kaku Press, Tokyo.

McCleave, J.D., Jellyman, D.J., 2004. Male dominance in the New Zealand longfin eel population of a New Zealand river: probable causes and implications for management. North Am. J. Fish. Manage. 24, 490-505.

Oliveira, K., 1997. Movements and growth rates of yellow phase American eels, Anguilla rostrata, in the Annaquatucket River, Rhode Island. Trans. Am. Fish. Soc. 126, 638-646.

Oliveira, K., 1999. Life history characteristics and strategies of the American eel, Anguilla rostrata. Can. J. Fish. Aquat. Sci. 56, 795-802.

Oliveira, K., McCleave, J.D., 2000. Variation in population and life history traits of the American eel, Anguilla rostrata, in four rivers in Maine. Environ. Biol. Fish. 59, 141-151.

Oliveira, K., McCleave, J.D., Wippelhauser, G.S., 2001. Regional variation and the effect of lake: river area on sex distribution of American eels. J. Fish Biol. 58, 943-952.

Parsons, J., Vickers, K.U., Warden, Y., 1977. Relationship between elver recruitment and changes in the sex ratio of silver eels $\mathrm{An}$ guilla anguilla L. migrating from Lough Neagh, Northern Ireland. J. Fish Biol. 10, 211-229.

Roncarati, A., Melotti, P., Mordenti, O., Gennari, L., 1997. Influence of stocking density of European eel (Anguilla anguilla, L.) elvers on sex differentiation and zootechnical performances. J. Appl. Ichthyol. 13, 131-136.

Rooker, J.R., Secor, D.H., Zdanowicz, V.S., Itoh, T., 2001. Discrimination of northern bluefin tuna from nursery areas in the Pacific ocean using otolith chemistry. Mar. Ecol., Prog. Ser. 218, 275-282.

Rooker, J.R., Secor, D.H., Zdanowicz, V.S., Metrio, G.D., Relini, L.O., 2003. Identification of Atlantic bluefin tuna (Thunnus thynnus) stocks from putative nurseries using otolith chemistry. Fish. Oceanogr. 12, 75-84.

Satoh, H., Nimura, Y., Hibiya, T., 1992. Sex control of the Japanese eel by an estrogen (DES-Na) in feed. Nippon Suisan Gakkaishi 58, 1211-1218.

Sinha, V.R.P., Jones, J.W., 1967. On the age and growth of the freshwater eel (Anguilla anguilla). J. Zool. 153, 119-137.

Svedäng, H., Neuman, E., Wickström, H., 1996. Maturation patterns in female European eel: age and size at the silver eel stage. J. Fish Biol. 48, 342-351.
Tatsukawa, K., 2003. Eel resources in East Asia. Eel Biology. Springer Press, Tokyo, pp. 293-298.

Tesch, F.W., 1977. The eel. Biology and Management of Anguillid Eels. Chapman and Hall Press, London.

Tsukamoto, K., 1992. Discovery of the spawning area for Japanese eel. Nature 356, 789-791.

Tsukamoto, K., 2006. Spawning of eels near a seamount: tiny transparent larvae of the Japanese eel collected in the open ocean reveal a strategic spawning site. Nature 493, 929.

Tsukamoto, K., Nak, I., Tesch, W.V., 1998. Do all fresh water eels migrate? Nature 396, 635-636.

Tzeng, W.N., 1984. An estimate of the exploitation rate of Anguilla japonica elvers immigrating into the coastal waters of Shuang-Chi River, Taiwan. Bull. Inst. Zool. Acad. Sin. 23, 173-180.

Tzeng, W.N., 1985. Immigration timing and activity rhythms of the eel Anguilla japonica elvers in the estuary of northern Taiwan with emphasis on environmental influences. Bull. Jpn. Soc. Fish. Oceanogr. 47/48, 11-28.

Tzeng, W.N., 1996. Effects of salinity and ontogenetic movements on strontium: calcium ratios in the otoliths of the Japanese eel, $A n$ guilla japonica Temminck and Schlegel. J. Exp. Mar. Biol. Ecol. 199, 111-122.

Tzeng, W.N., 1997. Short- and long-term fluctuations in catches of elvers of the Japanese eel, Anguilla japonica. Developing and Sustaining World Fisheries Resources: the State of Science and Management. Victoria, Australia: 2nd World Fisheries Congress Proceedings, pp. 85-89.

Tzeng, W.N., 2003. The processes of onshore migration of the Japanese eel Anguilla japonica as revealed by otolith microstructure. In: Aida, K., Tsukamoto, K., Yamauchi, K. (Eds.), Eel Biology. Springer-Verlag, Tokyo, pp. 181-190.

Tzeng, W.N., 2004. Modern research on the natural life history of the Japanese eel Anguilla japonica. J. Fish. Soc. Taiwan 31, 73-84.

Tzeng, W.N., Cheng, P.W., Lin, F.Y., 1995. Relative abundance, sex ratio and population structure of the Japanese eel Anguilla japonica in the Tanshui River system of northern Taiwan. J. Fish Biol. 46, 183-201.

Tzeng, W.N., Lin, H.R., Wang, C.H., Xu, S.N., 2000. Differences in size and growth rates of male and female migrating Japanese eels in Pearl River, China. J. Fish Biol. 57, 1245-1253.

Tzeng, W.N., Han, Y.S., He, J.T., 2002a. The sex ratios and growth strategies of wild and captive Japanese eels Anguilla japonica. In: Small, B., MacKinlay, D. (Eds.), Developments in Understanding Fish Growth. International Congress on the Biology of Fish. Univ. of British Columbia, Vancouver, Canada, pp. 25-42.

Tzeng, W.N., Shiao, J.C., Iizuka, Y., 2002b. Use of otolith Sr: Ca ratios to study the riverine migratory behaviors of Japanese eel Anguila japonica. Mar. Ecol., Prog. Ser. 245, 213-221.

Vladykov, V.D., 1966. Remarks on the American Eel (Anguilla rostrata LeSueur). Internationale Vereinigung fûr Theoretische und Angewandte Limnologie Verhandlungen, vol. 16, pp. 1007-1017.

Vøllestad, L.A., 1992. Geographic variation in age and length at metamorphosis of maturing European eel: environmental effects and phenotypic plasticity. J. Anim. Ecol. 61, 41-48.

Vøllestad, L.A., Jonsson, B., 1986. Life-history characteristics of the European eel Anguilla anguilla in the Imsa River, Norway. Trans. Am. Fish. Soc. 115, 864-871.

Westin, L., 1998. The spawning migration of European silver eel (Anguilla anguilla L.) with particular reference to stocked eel in the Baltic. Fish. Res. 38, 257-270. 